\title{
PENGEMBANGAN HUMAS EFEKTIF DI PERGURUAN TINGGI
}

\author{
Poppi Damayanti ${ }^{1}$ \\ Universitas Islam Negeri Fatmawati Sukarno Bengkulu ${ }^{1}$ \\ poppidamayanti@iainbengkulu.ac.id ${ }^{1}$
}

\begin{abstract}
ABSTRAK
Penelitian ini bertujuan untuk mengembangkan humas efektif di perguruan tinggi. Metode penelitian ini menggunakan studi kepustakaan. Hasil penelitian bawha Perguruan Tinggi (PT) sebagai pusat pendidikan tinggi generasi penerus bangsa, agen alih tehnologi dan inovasi, dalam perkembangan dan kiprahnya di tingkat masyarakat dituntut mengahasilkan produk-produk berkualitas, baik dalam hal lulusan, sistem pendidikan yang dikembangkan maupun tingkat kontribusinya pada pembangunan dalam arti luas. Dalam kiprah tersebut, perguruan tinggi memerlukan dukungan perangkat kerja tertentu yang dikenal dengan Public Relation (PR) atau Hubungan Masyarakat (Humas) untuk mengenalkan diri dan menunjukkan kemempuannya sebagai suatu lembaga pendidikan tinggi yang memiliki tradisi dalam bidang ilmu, pengetahuan dan seni (IPTEKS) tertentu, yaitu menyangkut isu-isu relevan dimunculkan, program unggulan dan dukungan yang dimilikinya. Simpulan penelitian bahwa penanganan humas efektif dapat dilihat dari fungsi dan perannya sebagai Marketing Public Relesen (MPR) dan Product Customer Satisfaction (PCS) yang mampu memberi penjelasan dan inencoba menjawab permasalahan yang terkait dengan produk-produk yang dihasilkan oleh Perguruan Tinggi bersangkutan.
\end{abstract}

Kata Kunci:Humas Effektif, Pengembangan, Perguruan Tinggi

\begin{abstract}
This study aims to develop effective public relations in universities. This research method uses literature study. Research results show that universities (PT) as centers of higher education for the nation's next generation, agents of technology and innovation transfer, in their development and work at the community level are required to produce quality products, both in terms of graduates, the education system developed and the level of their contribution to development. in a broad sense. In this work, universities need the support of certain work tools known as Public Relations (PR) or Public Relations (Humas) to introduce themselves and show their abilities as a higher education institution that has a tradition in certain fields of science, knowledge and art (IPTEKS). , namely regarding the relevant issues raised, the flagship program and the support it has. The conclusion of this research is that effective public relations management can be seen from its function and role as Marketing Public Relesen (MPR) and Product Customer Satisfaction (PCS) who are able to provide explanations and try to answer problems related to the products produced by the concerned university.
\end{abstract}

Keywords: Effective Public Relations, Development, Higher Education 


\section{PENDAHULUAN}

Pada dasamya Public Relation (PR) atau Hubungan Masyarakat (Humas) merupakan mere komunikasi yang meliputi berbagai teknik komunikasi. Dimana dalam kegiatanya terdapat usaha untuk mewujudkan hubungan yang harmonis antara suatu lembaga (Perguaruan dengan publiknya, atau usaha untuk mewujudkan opini publik yang favourable (Hutapea, 2000).

Kemajuan dan keberhasilan lembaga (Perguruan Tinggi) sangat ditentukan oleh citra yang dimiliki lembaga (Perguruan Tinggi) tersebut dimata stakeholdernya. Keberhasilan Perguruan Tinggi dalam membangun citra lembaga sangat ditentukan dengan adanya pengembangan manajemen terutama komunikasi baik pada public internal maupun public eksternal.

Hubungan Masyarakat (Humas) adalah sebuah alat manajemen (CART: Commitmett, Accountability, Relation Ponsibility dan Thrust atau RACE: Research, Action, Communicaticc dan Evaluation) yang sering disalahpahami dan disepelekan, baik di tingkat internal maupun eksternal, karena hanya dipandang sebagai bentuk lain (mitos) dari iklan, orang yang berhubung dengan wartawan dan mengirimkan siaran pers. Padahal dalam kenyataanya, Humas bekerjasecara professional melalui dukungan pengetahuan dan kemampuan dalam menulis.

Oleh karena itu perlu disadari pengertian tentang apa yang dapat dilakukan oleh Humas bagi pimpinan Perguruan Tinggi (Rektor/Ketua dan Pembantunya) dan organisasi Perguru Tinggi (PT) sendiri, yaitu bagaimana memproyeksikan pesan yang tepat ke pengguna melalui penguasaan komunkasi melakukan kegiatan promosi efektif sesuai biaya tersedia dan memanfaatkannya sebagai manajemen yang baik.

\section{METODE PENELITIAN}

Dalam penelitian ini menggunakan studi kepustakaan, yaitu studi yang objek penelitiannya berupakarya-karya kepustakaan baik berupa jurnal ilmiah, buku, artikel dalam media massa, maupun data-data dokumentasi. Kepustakaan tersebut digunakan untuk menjawab fokus masalah tulisan yakni pengembangan humas efektif di perguruan tinggi. Adapun sifat dari studi yang dilakukan adalah deskriptif analisis yaitu memberikan edukasi dan pemahaman kepada pembaca, serta jenis data yang digunakan dalam penelitian ini adalah data sekunder.

\section{HASIL DAN PEMBAHASAN}

\section{Konsep Public Relation/Hubungan Masyarakat (Humas)}

Menurut Broom (Effendi, 1989) Publik Relations adalah suatu fungsi manajemen yang menilai sikap publik, menunjukkan kebijaksanaan dan prosedur dari individu atau organisasi atas dasar kepentingan publik dan melaksanakan rencana kerja untuk memperoleh ui I pengertian dan pengakuan dari publik.

Selanjutnya Rahmadi (1996) mengatakan secara pengertian teoritis public relations merupakan salah satu bidang ilmu komunikasi praktis, yaitu penerapan ilmu komunikasi pada suatu lembaga atau perusahaan didalam menjalankan fungsi manajemen.

Sementara sasaran public relations menurut Kasali (2000) Publik yang menjadi sasaran Public Relations (PR) atau Hubungan Masyarakat (Humas) adalah:pertama, Publik Internal. Tujuan dari internal public relations adalah mencapai atau membuat karyawan agar mempunyai kegairahan bekerja. Untuk 
kearah ini dapat berhasilbila pihak pimpinan memperhatikan kepentingankepentingan para karyawan,baik ditinjau dari segi ekonomis, sosial maupunpsikologis. Kedua, Publik Eksternal. Tujuan dari exsternal public relations adalah untuk mencari serta mendapat dukungan dari publik yang berada di luar lembaga atau perusahaan tersebut.

Adapun bentuk-bentuk kegiatan eksternal public relations tersebut adalah: (1). Hubungan dengan pers (Press relations). Pers adalah media massa cetakmaupun elektronik, dalam hubungan ini kegiatankegiatan yang dilakukan adalah antara lain: (a). Menyiapkan bahan untuk press relase; (b). Menyiapkan dan melakukan interview dan konferens press; (c). MengadakanPublisitas; (d). Mengadakan Press tour. (2). Hubungan dengan pemerintah (Government relations). Pemerintah yang menjadi obyek hubungan adalah lembaga eksekutif legislatif. Selayaknya public relations menguasai peraturan dan kebijakaz, kebijakan pemerintah. (3). Hubungan dengan publik pelanggan (Customer relations). Kegiatan hubungan dengan pelanggan bisa dilakukan dengan periklanapublisitas serta promosi dagang, untuk memperluas kosumen atau pelangg survei pemasaran, ataupun mengukuran minat dan perhatian publik terha iklan. Hal ini menunjukkan bahwa pekerjaan public relations (PR) atau Hubungan Masyarakat (Humas) tidak sekedar pada kegiatan publikasi, tetapi juga kegiatan penelitian (pengumpulanfakta/data) (4). Hubungan dengan masyarakat luas (Communiti Relations). Hubungan dengan masyarakat luas 1 komunikasi berorientasi kepada kegiatan, yakni kegiatan yang dilakukan oleh lembaga perusahaan, dalam hal ini tents public relations sebagai pelaksanaanya yang bersifat partisipasi. Dengan partisipasi itu, maka keuntungan bukan hanya pada lembaga perusahaan saja. tetapi juga pada lingkungan disekitarnya. Macam bentuk partisipasi bisa berupa buah pikiran, tenaga, harta benda , keterampilan dan sosial.

\section{Publik Relations (PR) atau Hubungan Masyarakat (Humas) Sebagai Fungsi Manajemen}

Hubungan Masyarakat (Humas) adalah fungsi manajemen untuk membantu menegakkan dan memelihara aturan bersama dalam komunikasi, demi terciptanya saling pengertian dan kerjasama antara lembaga atau perusahaan dengan publiknya, membantu manajemen dan menanggapi pendapat publiknya, mengatur dan menekankan tanggungjawab manajemen dalam melayani kepentingan masyarakat, membantu manajemen dalam mengikuti, memonitor, bertindak sebagai suatu sistem.

Selanjutnya Terry (Hutapea, 2000) mendefinisikan manajemen merupakan sebuah proses yang Ichas, yang terdiri dari tindakan-tindakan : perencanaan, perorgonisasian, panggiatan dan pengawasan yang dilakukan untuk menentukan serta mencapai sasaran-sasaran yang telah ditetapkan melalui pemanfaatan sumber daya manusia dan sumber-sumber lainnya.

Perencanaan menurut Terry (Fauzi, 2000) meliputi tindakan memilih dan menghubungkan fakta-fakta dan membuat serta mengunakan asumsi-asumsi mengenai masalah yang akan datang dalam hal memvisualisasi serta merumuskan aktivitas-aktivitas yang diusulkan yang dianggap perlu untuk mencapai hasil-hasil yang diinginkan. 
Perorganisasiankeseluruhan aktivitas manajemen dalam mengelompokkan orang-orang serta menetapkan tugas, fungsi, wewenang dan tanggungjawab masing-masing dengan tujuan tercapainya aktivitas-aktivitas yang berdaya guna dan berhasil guna dalam mencapai tujuan yang telah ditentukan lebih dahulu.

Penggiatan atau pelaksanaan tidak lepas dari perencanaan, jadi apa yang telah direncanakan pada tahap terdahulu harus diwujudkan dalam tahap ini. Berkaitan dengan fungsi humas untuk menyebarkan informasi baik secara internal maupun secara ekseternal dapat menggunakan 4 macam media yaitu:Media cetak, segala barang cetak termasuk dalam media ini surat kabar, majalah, buku, brosur, dan lain-lain.Media visual ialah media yang dapat dilihat seperti foto, lukisan, film dan lain-lain.Media audif, ialah media yang dapat didengar seperti radio, garmapon, tape recorder, dan lain-lain.Dan media pertemuan, segala macam pertemuan termasuk dalam media ini, pertemuan antara dua orang, rapat formal, informal dan lain-lain.

Proses humas pada prinsipnya sama dan sejalan dengan proses komunikasi yaitu:Penelitian (Fact Finding). Tahap penelitian dalam humas, baik dalam memperoleh data primer dan sekunder, maupun penelitian bersifat research, secara kualitatif dan kuantitatif. Dan termasuk bersifat motivation research, yaitu penelitian yang tertentu pada jiwa manusia. Tentang kebutuhan dan keinginan yang paling mendasar.

Perencanaan (Planning). Penyusunan suatu program acara atau agenda setting dan program kerja humas, yang berpijak pada data dan fakta di lapangan, kebijakan, prosedur, tema dan kemampuan dana serta dukung dari pihak terkait.

Komunikasi (communication). Tahap komunikasi atau penggiatan adalah pelaksanaan secara aktif rencana yang telah disusun berdasarkan data faktual yang telah dikerjakan pada tahap-tahap sebelumnya. Dalam tahapan ini dibutuhkan komunikasi yang efektif dengan pendekatan persuasive, ada beberapa cirri komunikasi persuasive, yaitu: Informasi yang disampaikan harus didasarkan pada kebutuhan khalayak atau sasarannya, harus selalu berupaya membentuk pendapat yang positif dari sasarannya, dengan memberikan rangsangan atau stimuli, mendorong masyarakat sasaran untuk ikut serta, keikut sertaan ini akan merangsang terjadinya perubahan sikap, dan bila perubahan sikap telah terjadi, maka pembinaan perlu dilakukan agar partisipasi itu terpelihara.

Evaluasi (Evaluasi). Evaluasi atau penilaian berfungsi mengkaji pelaksanaan suatu rencana yang terdiri atas program-program yang dalam penyusunannya ditunjang oleh basil penelitian dilakuka: secara seksama.

Sejalan dengan pendapat di atas Uchjana (1989) menyimpulkan bahwa unsur-unsur manajemen yang meliputi planning, organizing. actuating, controlling menunjukkar, korelasi atau hubungan fungsional humas dengan manajemen dalam upaya mencapa tujuan dan sasaran organisasi dimana humas dan manajemen itu beroperasi. Dimana unsur-unsur itu trait mengkait secara holistik yang merupakan proses yang berkesinambungan.

\section{Fungsi dan Peran Humas}

Hubungan Masyarakat (Humas) adalah upaya terencana dan dilakukan terus menerus untuk mempertahankan itikad baik dan saling pengertian antara sebuah organisasi dan public. Humas bermanfaat untuk memastikan bahwa pengguna menerima dan memahami pesan yang diproyeksikan oleh pengirimnya. 
Pada prakteknya, humas dikeloia secara internal oleh karyawan sendiri (pelaksana dengan jabatan tertentu: Public Relations in house) atau oleh agen luar (Public Relation Consultant) atas landasan konsultasi, dengan fungsi untuk meningkatkan hubungan pers, periklanan, permasaran, pemberian/pencarian sponsor, penyelenggaraan pameran, acara masyarakat setempat, lingkungan dan urusan publik.

Oleh karena itu humas dapat dikatakan melibatkan banyak disiplin lainnya dan berdampak terhadap semua proses manajemen organisasi (membina dan mempertahankan identitas), baik internal (planning, organizing, staffing, leading dan controlling) dan eksternal (pengguna, pemasok, pemilik, pemerintah, masyarakat dll), diantaranya memainkan peranan pokok dalam memcapai tujuan spesifik pada semua tingkat pekerjaan organisasi, dengan memfokuskan, memperkuat dan mengkomunikasikan secara efektif, serta mengalokasikan sumberdaya semestinya.

Kebanyakan peranan humas bersifat mendasar dan langsung, serta tidak memerlukan biaya besar, sehingga humas dianggap sebagai metode yang baik dan efektif (investasi cerdik) untuk meningkatkan citra perorangan dan suatu organisasi atau produk dengan terencana (hasil baik dan reputasi meningkat). Hal ini erat kaitannya dengan kemampuan komunikasi, karena proses ini merupakan faktor kunci dalam berhubungan dengan masyarakat luas, yang ditunjukkan oleh kemampuan organisasi atau lembaga untuk tnengetahui dengan jelas tentang penggunanya dan memetik keuntungan dengan cepat dari citra publiknya yang semakin meningkat, dalam rangka membuat pengguna lebih berminat melakukan bisnis/kerjasama dengan kita, meningkatkan kedudukan kita di dalam masyarakat setempat, lebih memudahkan kita menarik dan mempertahankan team work berkaliber tinggi, menempatkan kita dalam pers ketika menginginkannya dan selalu berhasil.

\section{Humas Efektif}

Agar fungsi dan peran humas di Perguruan Tinggi menjadi efektif, maka perlu dilakukan langkah pengembangan yang sistematis dan terpadu (ROPE: Research, the setting of Objection, programming and Evaluation), baik dalam model, cara penanganan, ataupun program yang dikembangkan. Dalam hal ini perlu diruluskan tujuan program humas (who, why, how dan which) I dalam pengertian in sl view dan second view, karena pada umumnya humas sering menghadapi situasi yang tidak menyenangkan (permusuhan, curiga, apatis, dan penolakan) dari pihak internal I maupun eksternal.

Penanganan humas efektif dapat dilihat dari fungsi dan perannya sebagai marketing public relesen (MPR) dan product customer satisfaction (PCS) yang mampu memberi penjelasan dan inencoba menjawab permasalahan yang terkait dengan produk-produk yang dihasilkan oleh Perguruan Tinggi bersangkutan, memantuan perkembangan para pengguna jasa Perguruan Tinggi, mempromosikan langsung dan memanfaatkan hubungan baik dalam mengenalkan produk-produk Perguruan Tinggi (akademik dan non akademik).

Oleh karena itu, program humas perlu disesuaikan dengan arah perkembangan Perguruan Tinggi. Sebagai ilustrasi, pengembangan humas dapat dilakukan menurut periodisasinya, yaitu program 5 tahun pertama menjabarkan gagasan Perguruan Tinggi dalam pengembangan konsep sampai dengan aspek 
humasnya dan pada program 10 tahun berikutnya membangun impian dan harapan (aspek ide, aspek produksi, aspek penjualan, aspek promosi, aspek pendukung dan aspek public relesen). Hal tersebut menempatkan humas sebagai mediator, advisor dan komunikator, yang dicirikan oleh karakteristik seperti ramah, akrab, hangat, mudah diingat dan keringkasan dalam menyampaikan sesuatu.

Melalui peningkatan produk dan sisternnya, maka humas di Perguruan Tinggi diharapkan mampu membangun tradisi yang kuat tentang keberadaan suatu Perguruan Tinggi di masyarakat citra luar), terutama sebagai pilihan (prioritas) siswa dalam menempuh pendidikan lanjutnya jan tempat ercaya bagi para pengguna (pemerintah, swasta dan masyarakat luas) dalam melakukan konsultasipemecahan masalah yang dihadapinya dan pertukaran informasi, serta pusat alih teknologi dan inovasi segera diterapkan. Hal ini menunjukkan keinginan Perguruan Tinggi yang bersangkutan melalui humasnya menjadi pemenang dalam persaingan yang ketat untuk menembusdan membangun suatu kegiatan pendidikan tinggi yang bertradisi kuat.

\section{SIMPULAN}

Penanganan humas efektif dapat dilihat dari fungsi dan perannya sebagai Marketing Public Relesen (MPR) dan Product Customer Satisfaction (PCS) yang mampu memberi penjelasan dan mencoba menjawab permasalahan yang terkait dengan produk yang dihasilkan oleh Perguruan Tinggi bersangkutan, memantuan perkembangan para pengguna jasa Perguruan Tinggi, mempromosikan langsung dan memanfaatkan hubungan baik dalam mengenalkan produk-produk Perguruan Tinggi (akademik dan non akademik). Oleh karena itu, program humas perlu disesuaikan dengan arah perkembangan Perguruan Tinggi.

\section{DAFTAR PUSTAKA}

Effendy, O. U. (2000). Hubungan Masyarakat, Suatu Studi Komunikasi. Bandung. Remaja Karya

Fauzi, A. (2000). Proses Komunikasi Antara Organisasi dengan Publiknya, (Sebuah Tinjauan Kegiatan Hubungan Masyarakat). Jakarta. ISIP

Hutapea, E. B. (2000). Public Relations Sebagai Fungsi Manajemen. Jakarta. Fisip Universitas Bung Karno.

Jefkins, F. (1992). Hubungan Masyarakat. Jakarta. Internasa

Rahmadi, F. (1992). Publik Relations dalam Teori dan Praktek, Aplikasi dalam Badan Usaha dan Pemerintah. Jakarta. PT. Gramedia Pustaka Utama 